Int. Archs Allergy appl. Immun. 1986;81:I-V

\title{
Contents, Vol. 81, 1986
}

International Archives

of Allergy and Applied

Vol. 81, 1986

Immunology

Founded 1950 by D. Harley, P. Kallós,

W.

Löffler and F.W. Wittich

Continued by E.A. Brown (1952-1954)

$\mathrm{W}$

Kaufman (1955-1967),

F. Hahn (1961-1972), H.C. Goodman (1963-1975) and R.R.A. Coombs (1955-1984)

Editors-in-Chief

Contributing Editors

L.Å. Hanson, Göteborg

C.J. Abeyounis, Buffalo, N.Y.

W. Müller-Ruchholtz, Kiel

P. Kallós, Helsingborg

N.F. Adkinson, Jr., Baltimore, Md.

K.D. Murrell, Beltsville, Md.

K. Kano, Tokyo

St. Ahlstedt, Uppsala

F. Ørskov, Copenhagen

F. Milgrom, Buffalo, N.Y.

B. Albini, Buffalo, N.Y.

Ö. Ouchterlony, Göteborg 
K. Rother, Heidelberg

G. Andres, Buffalo, N.Y.

Z. Ovary, New York, N.Y.

Z. Trnka, Basel

E.L. Becker, Farmington, Conn.

P. Perlmann, Stockholm

G.B. West, Epsom

N. Blomqvist, Göteborg

E. Pick, Tel Aviv

W.E. Brocklehurst, Windlesham

M. Plaut, Baltimore, Md.

A. Capron, Lille

R.E. Reisman, Buffalo, N.Y.

A. Cerletti, Basel

G. Riethmüller, München

C.G. Cochrane, La Jolla, Calif.

M. Roitt, London

B. Diamant, Copenhagen

U. Rother, Heidelberg

P. Dukor, Basel

G. Sandberg, Stockholm

L. Edebo, Göteborg

H.D. Schlumberger, Wuppertal

S. Elsayed, Bergen

K.H. Schulz, Hamburg

W.P. Faulk, Nice 
A. Sehon, Winnipeg

P.G.H. Gell, Birmingham

F. Shakib, Derby !

I. Glazer, Tel Aviv

O. Strannegård, Göteborg

R.A. Good, St. Petersburg, Fla.

A. Szentivanyi, Tampa, Fla.

M. Hess, Bern

0. Tönder, Bergen

L. Hudson, Beckenham

G. Torrigiani, Geneve !

H. Isliker, Lausanne

J.L. Turk, London

S.G.O. Johansson, Stockholm

E.R. Unanue, Boston, Mass.

E.A. Kabat, New York, N.Y.

B.H. Waksman, New York, N.Y.

M. Miyasaka, Basel

G. Wick, Innsbruck

ffiffi

S. Karger · Medical and Scientific Publishers · Basel - München — Paris — London — New York - New Delhi · Singapore · Tokyo · Sydney

Drug Dosage 
The authors and the publisher have exerted every effort to ensure that drug selection and dosage set forth in this text are in accord with current recommendations and practice at the time of publication. However, in view of ongoing research, changes in government regulations, and the constant flow of information relating to drug therapy and drug reactions. the reader is urged to check the package insert for each drug for any change in indications and dosage and for added warnings and precautions. This is particularly important when the recommended agent is a new and/or infrequently employed drug.

All rights reserved.

No part of this publication may be translated into other languages, reproduced or utilized in any form or by any means, electronic or mechanical, including photocopying, recording, microcopying, or by any information storage and retrieval system, without permission in writing from the publisher or, in the case of photocopying, direct payment of a specified fee to the Copyright Clearance Center (see 'Information for Readers and Subscribers').

(C) Copyright 1986 by S. Karger AG, P.O. Box, CH-4009 Basel (Switzerland) Printed in Switzerland by Buchdruckerei Basler-Zeitung AG, Basel

Contents Vol. 81,1986

No. 1

Original Paper

Hemodynamic Response to Rapidly Infused 25\% Albumin in

Sheep: Blunting the Effects with Ibuprofen

Kay, J.; Traber, D.L 1

Effect of Interleukin-2 and Methylprednisolone on in vitro

Transformation of Uremic Lymphocytes

Langhoff, E.; Ladefoged, J.; Ødum, N

Prevalence of Specific IgE Antibodies against Piperazine in

Employees of a Chemical Plant

Hagmar, L.; Welinder, $\mathrm{H} \quad 12$

Factors Influencing the Enhancement of Delayed-Type Hyper-

sensitivity to Ovalbumin by Cyclosporin A in the Guinea

Pig: Possible Role of Suppressor Cells

Aldridge, R.D.; Thomson, A.W 17

Genetic Control of Delayed-Type Hypersensitivity in Mice to

Salmonella Antigen

Cho, N.; Saito-Taki, T.; Nakano, M 24

Induced Regional Differences, in Cutaneous Cell-Mediated Im

munity in the Mouse

Green, J.A.; Spruance, S.L 31

Human Splenic Fc Receptor Function and Dysfunction: Definition by Circulatory Clearance

Rate Compared to Computerized Kinetic Scintigraphy Lin, R.Y.; Racis, S.P.; Higginbotham-

Ford, E.; Tanz, W.S. 35

Plasminogen Activator Production from Murine Mastocytoma

Cells. Dissociation of Plasminogen Activator and Hista-

mine Production by Sodium Butyrate

Katayama, I.; Hashimoto, K; Nishioka, K 42

Effect of Functional Stimulation on Ascorbate Content in Phagocytes under Physiological and Pathological Conditions Oberritter, H.; Glatthaar, B.; Moser, U.; Schmidt, K.H. . 46 
Identification of HLA-Linked Antigens by Pregnancy-Associated Non-Cytotoxic Alloantisera MacLeod, A.M.; Mather, A.J.; Mason, R.J.; Stewart, K.N.;

Power, D.A.; Innes, A.; Catto, G.R.D 51

Homologous Passive Cutaneous Anaphylaxis in Various

Strains of Mice

Inagaki, N.; Goto, S.; Nagai, H.; Koda, A 58

Normal Chemotactic Migration of Polymorphonuclear Leuko

cytes Stimulated with Mononuclear-Derived Chemotactic

Factor in Ulcerative Colitis

Hermanowicz, A.; Nawarska, Z 63

IgGl Antibodies to House Dust Mite (Dermatophagoides faunae) and Late Asthmatic Response Ito, K; Kudo, K; Okudaira, H.; Yoshinoya, S.; Morita, Y.;

Nakagawa, T.; Akiyama, K; Urata, C; Hayakawa, T.;

Ohta, K; Nakada, S.; Horiuchi, T.; Takizwawa, H.; Shoji,

S.; Ishii, A.; Kitani, S.; Haida, M.; Yamashita, N.; Honda,

Z.; Miyamoto, $\mathrm{T}$

69

Development of a Competitive Radioimmunoassay for Human

Plasma Fibronectin

Ouaissi, M.A.; Neyrinck, J.L.; Capron, A 75

Effect of Drugs on the Increase in Cell Numbers in the Peritoneal Cavity of the Actively

Sensitised Mouse after Intraper-

itoneal Challenge with Antigen

Spicer, B.A.; Hatt, P.A.; Laycock, S.M.; Smith, H 81

Quality of Timothy Pollen (Phleum pratense) from Different

Pollen Seasons and Different Suppliers

Maasch, H.J.; Geissler, W.; Winter, H.G.; Wahl, R. ... 85

Short Communication

An Established MRL/Mp-lpr/lpr Cell Line with Null Cell Prop

erties Produces a B Cell Differentiation Factor(s) That Pro

motes Anti-Single-Stranded DNA Antibody Production in

MRL Spleen Cell Culture

Kanai, Y.; Katagiri, T.; Mori, S.; Kubota, T 92

Book Reviews 95

No. 2

Original Paper

Potentiated IgE Response in Nippostrongylus brasiliensis In

fested Rats - Sites of Synthesis and Traffic of Cells Secreting

Potentiated Antibody

Allan, W.; Mayrhofer, G 97

Affinity Chromatography and SDS-PAGE Studies of Radiola-

beled IgE-Binding and IgG-Binding Factors Generated

from Human Lymphoblastoid Cell Lines

Jensen, J.R.; Sand, T.T

104

Effects of Muramyl Dipeptide and Trehalose Dimycolate on Resistance of Mice to Toxoplasma gondii and Acantha-moeba culbertsoni Infections 
Masihi, K.N.; Bhaduri, C.R.; Werner, H.; Janitschke, K;

Lange, $\mathrm{W} \quad 112$

Monkey Interleukin 2: Optimal Conditions for Production and

Partial Characterization

Tatsumi, M.; Yabe, M118

Stimulating Effect of Unfractionated Heparin and a Low Mo

lecular Weight Heparin Fragment on the DNA Synthesis

Response of Human Thymocytes to Mercuric Chloride

Nordlind, K 126

Purification and Physiochemical Characterization of Schisto-soma mansoni Egg Allergen

Recognized by Mouse Sera Obtained at an Acute Stage of Infection Owhashi, M.; Horii, Y.;

Imai, J.; Ishii, A.; Nawa, Y. ... 129

Differential Effect of Experimental Diabetes on the Early and

Late Phase of Contact Sensitivity Reaction in Mice

Ptak, W.; Rewicka, M.; Gryglewski, A.; Bielecka, J 136

IV

Contents

IgG Subclass of Human Serum Antibodies Reactive with Dietary Proteins

Barnes, R.M.R.; Harvey, M.M.; Blears, J.; Finn, R.; John

son, P.M 141

Potentiation of the Cellular Immune Response by Adjuvants:

A Limited Role for Adjuvant Induced Interferon

Kraaijeveld, C.A.; Kamphuis, W.; Benaissa-Trouw, B.J.;

van Haarlem, H.; Harmsen, M.; Snippe, H 148

Feedback Regulation of Antibody Formation by Suppressive B

Cell Factor: Preferential Suppression of High-Affinity Anti

body Production by Memory B Lymphocytes

Park, Y.-H.; Suzuki, T.; Miyama-Inaba, M.; Masuda, T.;

Yoshida, Y.; Uchino, H 156

In vitro Effects of Sodium Lauryl Sulfate on DNA Synthesis

and Fine Structure of Human Thymocytes

Nordlind, K.; Thyberg, J 165

Local Intranasal Immunotherapy with High-Dose Polymerized Ragweed Extract

Georgitis, J.W.; Nickelsen, J.A.; Wypych, J.I.; Barde, S.H.;

Clayton, W.F.; Reisman, R.E 170

Analysis by Electrophoretic Transfer Blotting of Japanese Ce

dar Pollen Allergens which React with IgG and IgE Anti

bodies in the Serum of Patients

Ito, Y.; Yoshinaka, Y.; Ohi, M.; Sakakura, Y174

Short Communications

Induction of Suppressor Cells in Normal Lymphocytes by Ure-

mic Serum

Weissgarten, J.; Modai, D.; Cohen, N.; Averbukh, Z.;

Shaked, U.; Tieder, M.; Peller, S.; Kaufmann, S 180 
Use of Steroidal Antiinflammatory Drug Provides Further Evidence for a Potential Role of PAFAcether in Bronchial

Anaphylaxis

Chignard, M.; Le Couedic, J.P.; Andersson, P.; Brange, C. 184 Liposomes as Carrier for

Antibiotics: A Comparative Study on

the Immune Response against Liposome-Encapsulated

Penicillin and Other Penicillin Preparations

de Haan, P.; Claassen, E.; van Roijen, N 186

Complement Activation by Female Protein, the Hamster Ho-

mologue of Human C-Reactive Protein

Etlinger, H.M.; Coe, J.E 189

Book Reviews 192

No. 3

Original Paper

A Re-examination of Ryegrass (Lolium perenne) Pollen Aller

gens

Ford, S.A.; Baldo, B.A

Studies on Hanganutziu-Deicher Antigens-Antibodies. I. Hanganutziu-Deicher Antibodies of IgG Class in Liver Diseases

Morito, T.; Nishimaki, T.; Masaki, M.; Yoshida, H.; Kasu-

kawa, R.; Nakarai, H.; Kano, K 204

Effect of Gamma Globulin Infusion on Type-Specific Pneumococcal Antibody Levels in Splenectomized Adults

Offenbartl, K.; Christensen, P.; Gullstrand, P.; Prellner, K.;

Henrichsen, J 209

Isolation and Characterization of Two Allergens from Derma-

tophagoides faunae

Yasueda, H.; Mita, H.; Yui, Y.; Shida, T 214

Specific Immunological Modulation of Lymphocyte Adenylate Cyclase in Asthmatic Patients after Allergenic Bronchial Provocation

Meurs, H.; Kauffman, H.F.; Timmermans, A.; de Monchy,

J.G.R.; Koëter, G.H.; de Vries, K 224

Monocytes Constitute the Only Peripheral Blood Cell Popula

tion Showing and Increased Burst Activity in Multiple Scle

rosis Patients

Hammann, K.P.; Hopf, H.C 230

Enhancement of Leukocyte Membrane Receptor Expression

after Mechanical Agitation

Næss, A.; Halstensen, A.; Solberg, CO 235

Raised Serum IgG4 Levels in Patients with Atopy and Filaria-

sis: Application of an Automated Particle-Counting Immu-

noassay Using Monoclonal Antibody

Magnusson, C.G.M.; Cesbron, J.Y.; Djurup, R.; Capron,

A.; Johansson, S.G.0 238

Immunomodulating Properties of Substances to Be Used in Combination with Liposomes 
Zigterman, G.J.W.J.; Jansze, M.; Snippe, H.; Willers,

J.M.N 245

Enzyme-Linked Immunosorbent Assay (ELISA) Inhibition

Method to Estimate the Level of Airborne Bovine Epider

mal Antigen in Cowsheds

Virtanen, T.; Louhelainen, K.; Mäntyjärvi, R253

Contact-Sensitizing and Tolerogenic Properties of 2,4-Dinitro-thiocyanobenzene Kimber, I.;

Botham, P.A.; Rattray, N.J.; Walsh, S.T. ... 258

Inhibition of Rhesus Monkey Airway and Cutaneous Responses to Platelet-Activating Factor

(PAF) (AGEPC) with the Anti-PAF Agent SRI 63-072 Patterson, R.; Harris, K.E.; Lee, M.L.;

Houlihan, W.J. . . 265

Enzyme Immunoassay with Cell Suspensions: Studies on Reactions between Serum Antibodies

and Cell-Surface Antigens Wasik, M.; Muirhead, D.; Rubocki, R.; Milgrom, F. ... 269

Functional Evaluation of the Basophil/IgE System in the Cord Blood

Miadonna, A.;Tedeschi, A.;Leggieri, E.;Motta, G.;Fabbri, C; Froldi, M.; Agosti, M.; Lorini, M.;

Marini, A.; Zanussi, C. 276

Short Communication

Changes in IgG and IgE Antibody Levels to Bee Venom during

Immunotherapy

Ferrante, A.; Mocatta, F.; Goh, D.H.B 284

Books Reviews 288

No. 4

Original Paper

Intraepithelial Migration of Mucosal Mast Cells in Hay Fever:

Ultrastructural Observations

Enerbäck, L.; Pipkorn, U.; Olofsson, A 289

Contents

$\mathrm{V}$

Purification and Characterization of Two Protein Antigens

from the Heterogenous BCG85 Complex in Mycobacterium

bovis $\mathrm{BCG}$

Wiker, H.G.; Harboe, M; Lea, T.E 298

MPB59, a Widely Cross-Reacting Protein of Mycobacterium

bovis BCG

Wiker, H.G.; Harboe, M.; Nagai, S.; Patarroyo, M.E.;

Ramirez, C; Cruz, N 307

Comparative Studies on Tree Pollen Allergens. XI. Trials on

the Regulation of IgE Response in Mice Using Modified

Birch Pollen Allergens

Vik, H.; Elsayed, S 315

Impaired Cutaneous Delayed-Type Hypersensitivity in Autoimmune MRL 1pr/lpr Mice

Carlsten, H.; Nilsson, L.-Å.; Tarkowski, A 322

Split Immunosuppression of Contact Cell-Mediated and of IgE

Hypersensitivity Responses to Dinitrofluorobenzene in

Mice 
Ben-Efraim, S.; Mor, S.; Gal, T.; Ben-David, A.; Gitter, S. 326 The Immunocompetence of Children with Congenital Heart

Disease

Radford, D.J.; Lachman, R.; Thong, Y.H 331

Mucosal Mast Cells as a Component of the Inflammatory

Response to Lower-Urinary Tract Infection

Cornish, J.; Vanderwee, M.A.; Ormrod, D.J.; Miller, T.E. 337 Mitogenic Responses of Splenic B and T Lymphocytes in Neo-

natally Capsaicin-Treated Mice

Sandberg, G.; Ljungdahl, § 343

Effects of Thiazinamium Chloride on Histamine Release from

Rat Peritoneal Mast Cells and on Phosphodiesterase Activity in Guinea Pig Lung

Carlson, R.P.; O’Neill-Davis, L.; Chang, J.; Lewis, A.J. . 348 Studies on Auto-Anti-Idiotypic

Thyroid-Stimulating Antibodies

Beall, G.N.; Rapoport, B.; Chopra, I.J.; Kruger, S.R. ... 351

Suppression of Murine IgE Responses with Amino Acid Polymer/Allergen Conjugates. IV.

Suppressive Activities in Established IgE Model Systems Moran, D.M.; Wheeler, A.W.;

Henderson, D.C.; Whittall, N. 357

Airway Hyper-Reactivity and Blood, Lung and Airway Eosino-

philia in Rats Treated with Sephadex Particles

Laycock, S.M.; Smith, H.; Spicer, B.A 363

Modulating Effect of Beta-Endorphin, Somatostatin, Substance

$\mathrm{P}$ and Vasoactive Intestinal Peptide on the Proliferative

Response of Peripheral Blood T Lymphocytes of Nickel-

Allergic Patients to Nickel Sulfate

Nordlind, K.; Mutt, V 368

Short Communications

Stimulation of Human Blood Mononuclear Cell Procoagulant

Activity by Cyclosporin A

Webster, L.M.; Thomson, A.W

Changes in the Coagulation System during Pseudoallergic Ana-

phylactoid Reactions to Drugs and Food Additives

Zimmermann, R.E.; Czarnetzki, B.M375

Effect of Serotonin on T Lymphocyte Proliferation in vitro in

Healthy Individuals

Khan, LA.; Bhardwaj, G.; Malla, N.; Wattal, C; Agarwal, S.C. 378 Analysis of Histamine-

Binding Lymphocytes in Atopy

Ruby, J.; Douglass, J.; Czarny, D.; Muller, H.K 381

Clearance of Passively Tansferred IgE Antibody from Peripheral Blood of Mast Cell-Deficient

$\mathrm{W} / \mathrm{Wv}$ Mice

Watanabe, N.; Owhashi, M.; Nawa, Y 385

Calcium and Histamine Release from Mast Cells

West, G.B 388

Book Reviews

News Item 392

Author Index 393 